\title{
Assessing the status of pinuchu as indicator of socio-ecological resilience of Chaya Socio-Ecological Production Landscape, Ifugao, Philippines
}

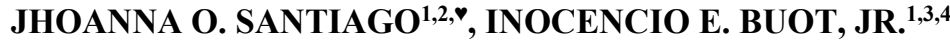 \\ ${ }^{1}$ School of Environmental Science and Management, University of the Philippines Los Baños. College, Laguna 4031, Philippines. Tel.: +63-49-536 2836, \\ email: josantiago1@up.edu.ph \\ ${ }^{2}$ Department of Agriculture-Regional Field Office CALABARZON. Diliman, Quezon City, Philippines \\ ${ }^{3}$ Institute of Biological Sciences, College of Arts and Sciences, University of the Philippines Los Baños. College, Laguna 4031, Philippines \\ ${ }^{4}$ Faculty of Management and Development Studies, University of the Philippines Los Baños. College, Laguna 4031, Philippines
}

Manuscript received: 8 August 2018. Revision accepted: 16 October 2018.

\begin{abstract}
Santiago JO, Buot Jr IE. 2018. Assessing the status of pinuchu as indicator of socio-ecological resilience of Chaya SocioEcological Production Landscape, Ifugao, Philippines. Biodiversitas 19: 2010-2019. Safeguarding biodiversity should be one of the priorities of the community to attain resilience. This study was aimed to determine the conditions of the woodlot (pinuchu) along the altitudinal zones of the mountain ranges in Chaya and correlated this to resilience. Specifically, it aimed to (i) determine the species composition, structure, and diversity of the tree species in selected pinuchu and (ii) determine the environmental variables associated with the vegetation composition. Vegetation data were subject to classification and ordination analyses. Species diversity was also calculated using Shannon-Wiener index. The tree diversity showed an overall diversity of $\left(\mathrm{H}^{\prime}=3.83\right)$ corresponding to relatively high diversity. According to canonical correspondence analysis (CCA), elevation, temperature, and human disturbances influenced the vegetation composition. It is recommended that to sustain resilience of the CSEPL, pinuchu should be biodiversity-rich at all times. Policymakers should use native species as planting material in the reforestation program instead of using fast-growing exotic species.
\end{abstract}

Keywords: Biodiversity, resilience, socio-ecological production landscape, pinuchu

\section{INTRODUCTION}

Biodiversity plays a vital role in ecosystem resilience and in sustaining desirable ecosystem attributes (Peterson et al. 1998). In the context of socio-ecological production landscape, biodiversity is considered significant for it contributes to resilience by providing ecosystem services and acts as buffer against perturbations (Bergamini et al. 2014; Jacobi et al. 2013).

Indeed, biodiversity is really an integral part of resilience (Jacobi et al. 2013). Hence, in this study, the storehouse of biodiversity in a socio-ecological production landscape (SEPL), the pinuchu, was investigated. Pinuchu or muyong in other dialect (Banaue) is a private woodlot with clearly demarcated boundaries owned and maintained by Ifugao families or clans (Soriano and Herath 2018). Diverse tree species have unique ecological values contributing to landscape functioning. The pinuchu serves as a watershed ensuring an all-year-round supply of water for the rice field (Camacho et al. 2016) and in fact unknowingly to lowland rivers as well. The pinuchu protects the lower farmlands from runoff and erosion (Serrano and Cadaweng 2005). In addition, the pinuchu provides firewood, fruits, lumber and medicinal plants (Castonguay et al. 2016). It is also the major source of wood for wood carving industry in Ifugao (DENR, 2008). The pinuchu helps regulate hydrology and microclimate thereby providing buffer against extreme weather events (Bergamini et al. 2014). This demonstrates the importance of biodiversity of pinuchu in sustaining the integrity of the whole landscape.

This means that safeguarding biodiversity should be one of the priorities of the community to attain resilience. However, information on the status of the biodiversity in the forest of Chaya has not been studied and thus a baseline information is required to serve as guide in measuring ecological indicators of socio-ecological resilience. This will lead to the formulation of management and conservation strategies. Hence, this study aims to (i) determine the species composition, structure, and diversity of the tree species in selected pinuchu and (ii) determine the environmental variables associated with the vegetation composition.

\section{MATERIALS AND METHODS}

\section{Study area}

The study was conducted in Barangay Chaya, Mayoyao, Ifugao, Philippines (Figure 1). The study sites were the mountain slopes of Bfu-lak, Nagchayan and Munchipfichib. These three mountains surrounded the Chaya Rice Terraces, one of the eight rice terraces of Central Mayoyao Rice Terraces inscribed as UNESCO World Heritage Site in Mayoyao, Ifugao. Barangay Chaya's climate is classified as Type III. Rainfall is significant in most months of the year, and the short dry season has negligible effect (Figure 2). The northeast monsoon locally known as "amihan" and the Pacific trade winds influence the climate of the village. Heaviest rains occur during the months of July to November with an average annual rainfall of 1,651.4 mm. Precipitation is lowest in February with an average of $23 \mathrm{~mm}$. 


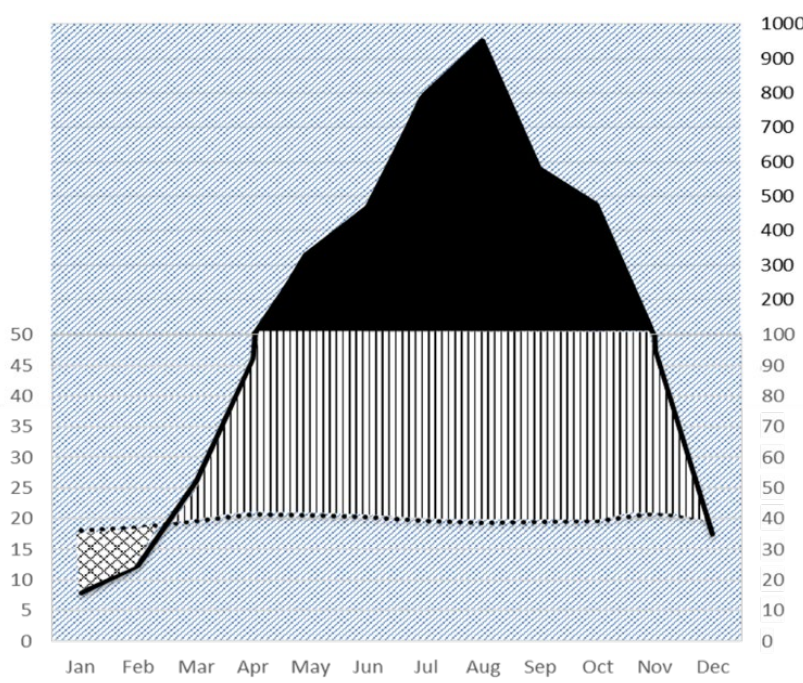

...... Average temperature $\longrightarrow$ Average rainfall

Figure 2. Climograph for Baguio City, the nearest weather station to Chaya, Mayoyao, Ifugao, Philippines (Data source: PAGASA, 1985-2016 climate data)

Generally, the climate is cool with temperature ranging from $16^{\circ} \mathrm{C}$ to $20^{\circ} \mathrm{C}$. It is relatively dry from March to May and generally wet for the rest of the year. The coolest months are November, December, and January, while the hottest month is April. Barangay Chaya has a very steep and mountainous terrain with high ridges, deep valleys and with waterfalls from rivers, creeks, and brooks coming from barangay Liwo River flowing down to Peñanga and Magat River. The forested mountains in the uppermost part of the barangay is regarded as important for it is the watershed area which serves as water source of the barangays.

\section{Methods}

Biodiversity was identified as important ecological indicator of resilience in Chaya Socio-ecological production landscape in the study by Santiago and Buot (2018). Vegetation analysis was used to describe the conditions of pinuchu of Chaya. Vegetation sampling was done in the selected pinuchu in the mountains of Bfu-lak, Nagchayan and Munchipfichib. In determining the plots, random sampling was done per elevation starting from $1000 \mathrm{~m}$ to $2000 \mathrm{~m}$ altitude. Every plot was set up at $100 \mathrm{~m}$ interval from the foot slope up to the peak of the three mountains. A total of fifteen (15) plots of $10 \times 10 \mathrm{~m}^{2}$ size were established in the entire sites (Figure 1). All woody tree species with a height of about $1 \mathrm{~m}$ were identified. The scientific names and local names were recorded. Diameter at breast height $(\mathrm{DBH})$ and total height of each species were recorded (Figure 3).

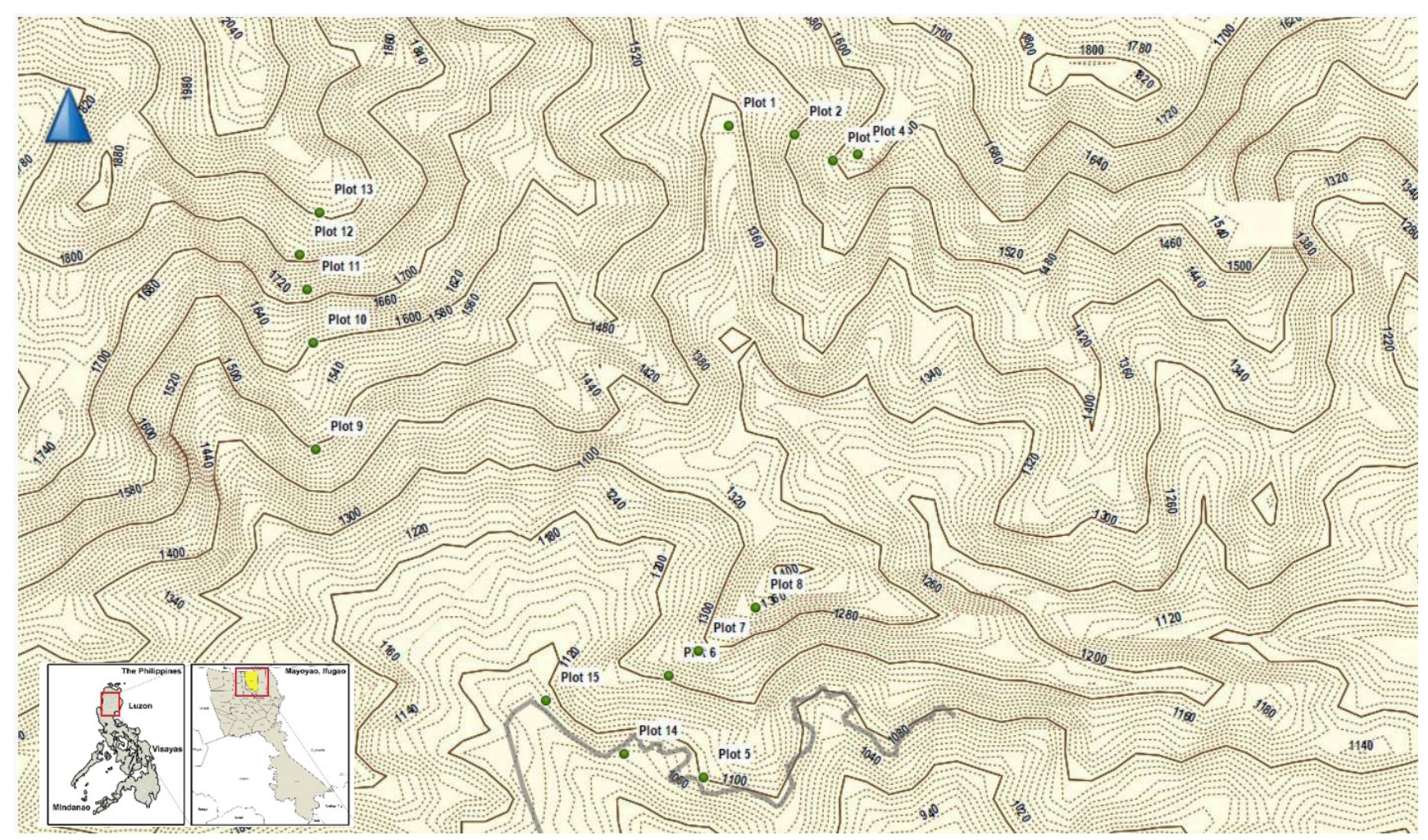

Figure 1. The study area showing the sampling plots (green dots). Lower left inset map shows the location of Mayoyao, Ifugao in the Philippines and the location of Barangay Chaya in Mayoyao (Generated using QGIS) 


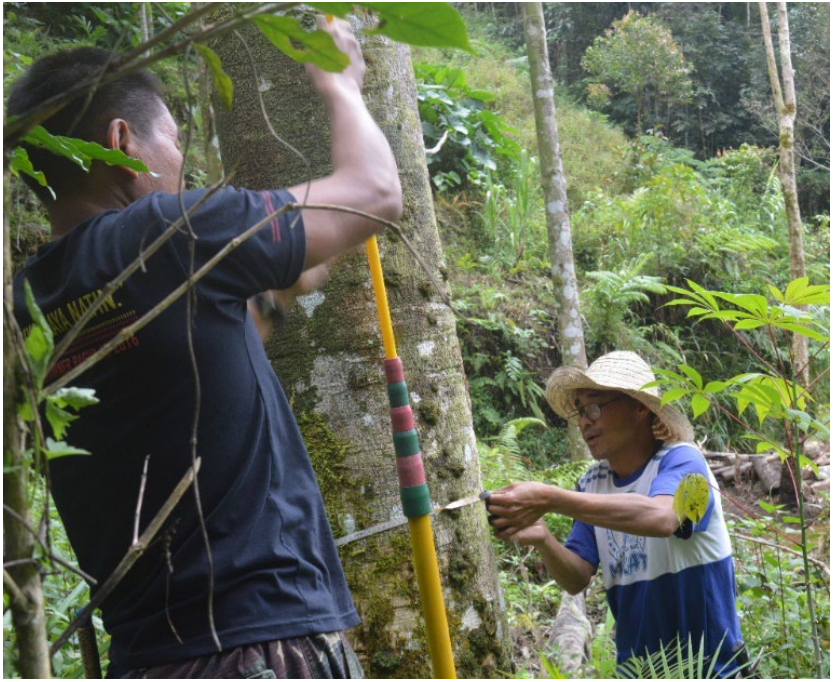

Figure 3. Two residents of Chaya, Mayoyao, Ifugao, Philippines helping in the collection of vegetation data

Basal area was computed from DBH data using the equation;

$$
\text { Basal area }(\mathrm{BA})=0.7857 \times \mathrm{D}^{2}\left(\mathrm{~cm}^{2}\right)
$$

Where, $\mathrm{D}=$ diameter at breast height (Cintron and Novelii 1984).

The dominant species were identified and calculated based on the relative basal area (RBA) derived from DBH values and the dominant species was determined using the equation by Ohsawa (1984):

$$
d=\frac{1}{\mathbb{N}}\left\{\sum_{\mathrm{ieT}}\left(\mathrm{x}_{\mathrm{i}}-\overline{\mathrm{x}}\right)^{2}+\sum_{\mathrm{ieU}} \mathrm{x}^{2} \mathrm{j}\right\}
$$

Where, $d=$ the deviation, $x_{i}=$ the actual percent share [in this case, the RBA] of the top species (T), i.e., the top dominant in the one-dominant model, or the two top dominants in the two-dominant model and so on, $\bar{x}=$ the ideal percent share based on the remaining species (U) and $\mathrm{N}=$ the total number of species.

RBA was further subjected to classification and ordination analyses using Paleontological Statistics (PAST) version 3.13. Cluster analysis was done using Bray-Curtis similarity index. A dendrogram was then constructed using the Unweighted Pair Group Method with Arithmetic mean (UPGMA) algorithm (Sneath and Sokal 1973).

Physical and environmental data such as elevation, coordinates, and disturbances in each site were noted. In each plot, composite random soil samples were taken from the topsoil (up to $30 \mathrm{~cm}$ below ground). Each soil sample was analyzed for $\mathrm{pH}$, Nitrogen $(\mathrm{N})$ and Phosphorous $(\mathrm{P})$ content using the UPLB Soil Test Kit. Temperature at different altitude was extracted from the climatic data from Philippine Atmospheric and Geophysical Astronomical Services Administration (PAGASA) using the assumption of Sarmiento (1986) that for every $100 \mathrm{~m}$ elevation rise, there is a corresponding decrease of $0.6^{\circ} \mathrm{C}$ of temperature.
The Canonical Correspondence Analysis (CCA) of Ter Braak (1987) was used to pinpoint which environmental data are influencing species RBA.

Tree diversity was measured using the Shannon-Wiener index of diversity computed as follows:

$$
H^{\prime}=-\sum_{i=1}^{s} p i \ln p i
$$

Where, $\mathrm{S}=$ the number of species

$p i=$ the relative abundance of each species, calculated as the proportion of individuals of a given species to the total number of individual in the community: $\frac{n_{i}}{N}$

$n_{i}=$ the number of individuals in species $\mathrm{i}$

$\mathrm{N}=$ the total number of all individuals

Sample specimens of unknown species were identified by an expert of College of Forestry and Natural resources, University of the Philippines Los Baños (UPLB) using the lexicon of Philippine Trees (Rojo, 1999). Nomenclature follows that of the International Plant Name Index (IPNI) website (https: //www.ipni.org), Co's Digital Flora of the Philippines (http://www.philippineplants.org/), Fernando et al (2004), Backer and Bakhuizen v.d. Brink (1965) and Merill (1923). Voucher specimens of the unidentified plants were deposited at the Herbarium of the Plant Biology Division, Institute of Biological Sciences (PBDH), University of the Philippines Los Baños, Laguna, Philippines. Photographs of these specimens were also deposited at the herbarium.

\section{RESULTS AND DISCUSSION}

\section{Species composition, structure, and diversity}

Table 1 showed the structural characteristics of the species composition of each zone. The number of species, species diversity, maximum DBH and the RBA per plot were also indicated for comparison. A total of 88 species were found in the entire woodlot, 67 of which belong to 35 families such as Pinaceae, Lauraceae, Moraceae, Rubiaceae, and Fagaceae and others. On the other hand, 16 species were identified only at their local name level and the remaining five were not identified.

Using the RBA, the species were subjected to cluster analysis forming two big zones with each two sub-zones (Figure 4). Each zone was named according to the dominant species.

Zone I (Pinus-Gmelina-Swietenia) or the Near Residence Zone: This zone was in the lower elevation $(1050 \mathrm{~m}$ to $1200 \mathrm{~m})$ of Mount Nagchayan. This zone was dominated by Pinus kesiya Royle ex Gordon, Gmelina arborea Roxb. and Swietenia macrophylla King. The highest RBA was 100 found in plot 7 while the lowest RBA was 0.01 found in plot 14 (Table 1). The maximum DBH value was $54 \mathrm{~cm}$ found in sampling plot 8 . The species diversity ( $\left.\mathrm{H}^{\prime}\right)$ in Zone 1 was 2.98 dit. This is considerably lower than Zone 2 mainly because this zone was near the residential area and most of the plots were 
reforestation sites. The soil in Zone I had $\mathrm{pH}$ ranging from 6-6.4. Nitrogen content was found to be high in plots 14 and 15 while Phosphorus content was high in plots 6,7 and 8 .

Subzone Ia (Gmelina-Bischofia-Palaquim). At similarity level of 0.05 , Zone I was further divided into two zones. The first zone was composed of plots 5, 14 and 6 and was dominated by Gmelina arborea Roxb., Bischofia javanica Blume and Palaquium luzoniense S.Vidal. The species diversity (H') was 2.941 dit.

Subzone Ib (Pinus-Swietenia-Citrus). This zone was composed of plots 7 and 8 and was dominated by Pinus kesiya Royle ex Gordon, Swietenia macrophylla King and Citrus maxima (Burm.) Merr. The species diversity (H') was 1.745 dit.

Zone II (Lithocarpus-pfoloblo-Toona-ElaeocarpusCleistocalyx-unknown) or Forest Zone. This zone was composed of plots 1,2,3,4,9,10,11,12 and 13 located in Mount Bfu-lak and Mount Munchipfichib from $1300 \mathrm{~m}$ to $2000 \mathrm{~m}$ asl. This was dominated by Lithocarpus submonticola (Elmer) Rehder, pfoloblo (local name), Toona calantas Merr. \& Rolfe, Elaeocarpus sp., Cleistocalyx operculatus (Roxb.) and another unknown species. The highest RBA was 80.92 found in plot 12 while the lowest was 0.01 found in plot 9 . This site had a species diversity of 3.49 dit. The maximum DBH value was $54 \mathrm{~cm}$ found in sampling plot 12. The soil in Zone II had $\mathrm{pH}$ of 6 . Nitrogen content was found to be low to medium while Phosphorus content varied from low to high.

Subzone IIa (Toona-unknown 3-RadermacheraElaeocarpus-Luecosyke). At similarity level of 0.08 , the Zone II was divided into two sub-zones. Sub-zone IIa was dominated by Toona calantas Merr. \& Rolfe, unknown 3, Radermachera acuminata Merr., Elaeocarpus sp. and Leucosyke capitellata Wedd. The species diversity (H') was 3.331 dit.
Subzone IIb (Lithocarpus-pfoloblo-Litsea). This was composed of plots 1, 2, 12 and 13 and dominated by Lithocarpus submonticola (Elmer) Rehder, pfoloblo and Litsea perrottets (Blume) Fern.-Vill. The species diversity (H') was 3.058 dit.

The species diversity ( $\left.\mathrm{H}^{\prime}\right)$ for the entire Chaya was 3.83 dit.

\section{Discussion}

The floristic characters of pinuchu along different elevation of chaya mountain ranges

The floristic composition of the pinuchu in Chaya Socio-Ecological Production Landscape (CSEPL) is comparable to the results of Magcale-Macandog et al (2013), Taguiling (2014) and Rabena (2015) in various woodlots in the municipalities of Ifugao. The species were of northern character except Gmelina arborea Roxb. and Swietenia macrophylla which were introduced species.

The pinuchu forest structural features along altitudinal gradient were illustrated in Figure 5.A to 5.F. The number of species per sampling site increased with increasing elevation as with species diversity (Figure 5.A-5.B). Ideally, these two parameters should decrease towards higher altitudes because of the low temperature in higher elevation based on the observation of Buot and Okitsu (1998) and Banaticla and Buot (2005). The inverse relationship could be attributed to the proximity of pinuchu to the residential area. Since these were located at the lower elevation, humans could easily access the woodlot for their timber needs. The anthropogenic disturbance could jeopardize the structural characteristics of the forest as observed in the study of Buot and Osumi (2011) in Mount Makiling. Meanwhile, the dbh and height were decreasing at increasing elevation.

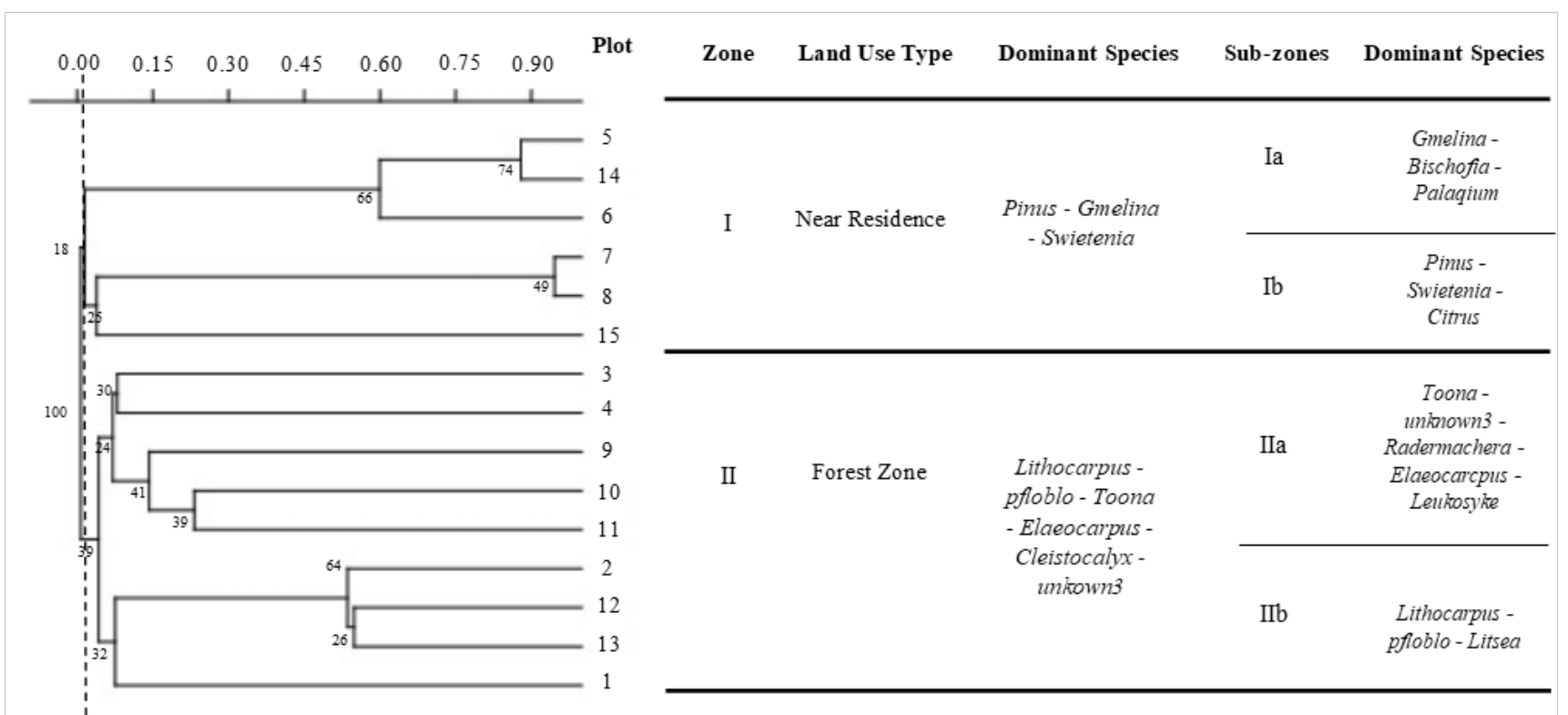

Figure 4. The dendrogram constructed using Unweighted Arithmetic Average Clustering (UPGMA) showing the two zones and their respective dominant species and land use types. Bootstrapping was done at $\mathrm{n}=100$, cophenetic correlation is 0.9719 
The structure of the biodiversity of Chaya's pinuchu was illustrated in a dendrogram (Figure 4) with a simple zonation pattern of two zones, each composed of two subzones, with Zone I (pine forest) and Zone II (mossy forest). This type of zonation is similar to Mount Akiki and Mount Pulag landscape having a pure and mixed Pinus zone and an extensive montane forest dominated by Lithocarpus (Buot 2007; Buot and Okitsu 1999). The only difference for this study is the presence of
Gmelina arborea Roxb and Swietenia macrophylla King indicating that there were already anthropogenic disturbances. In Ifugao, pinuchu owners preferred hardwood species for their wood carving and house construction. Gmelina arborea Roxb and Swietenia macrophylla King are the most common reforestation species being planted nowadays considering their short rotation period and widespread availability (Camacho et al. 2016).

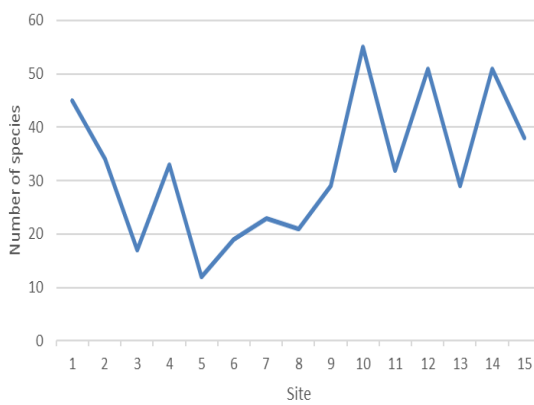

A

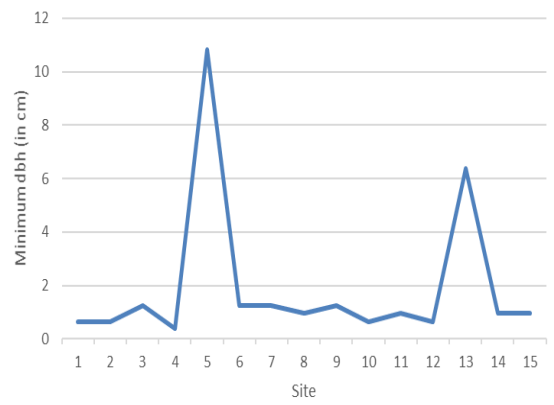

D

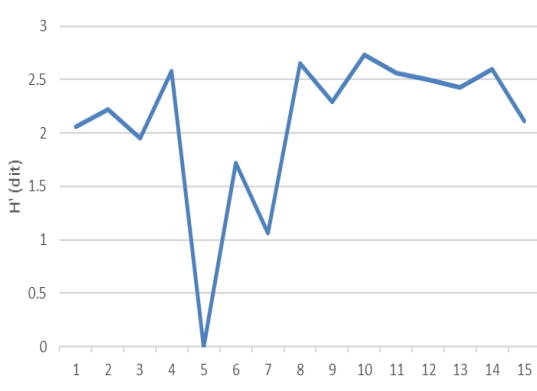

B

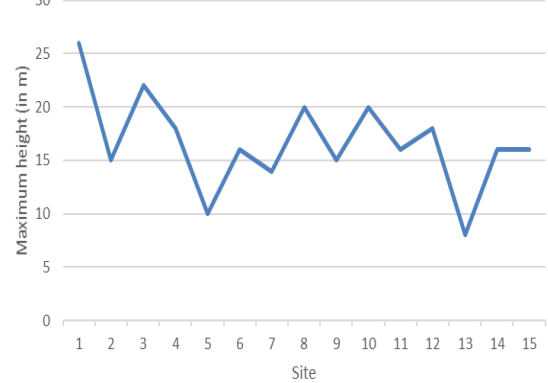

$\mathbf{E}$

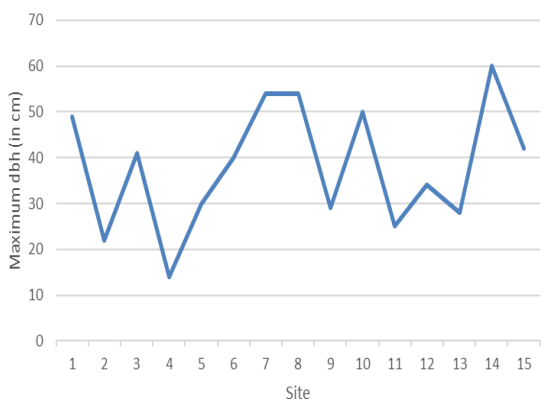

C

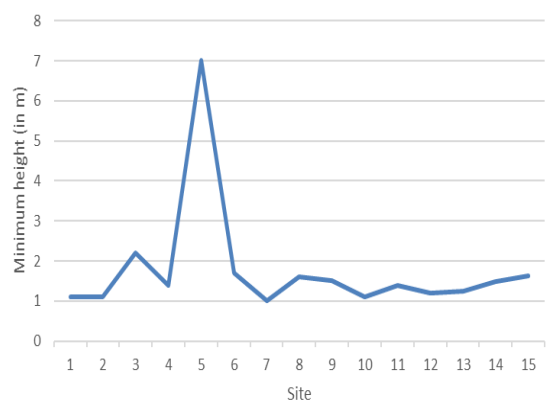

$\mathbf{F}$

Figure 5. The forest structural features along altitudinal gradients of Chaya, Mayoyao, Ifugao, Philippines. A. Number of species, B. Species diversity, C. Maximum dbh, D. Minimum dbh, E. Maximum height, F. Minimum height

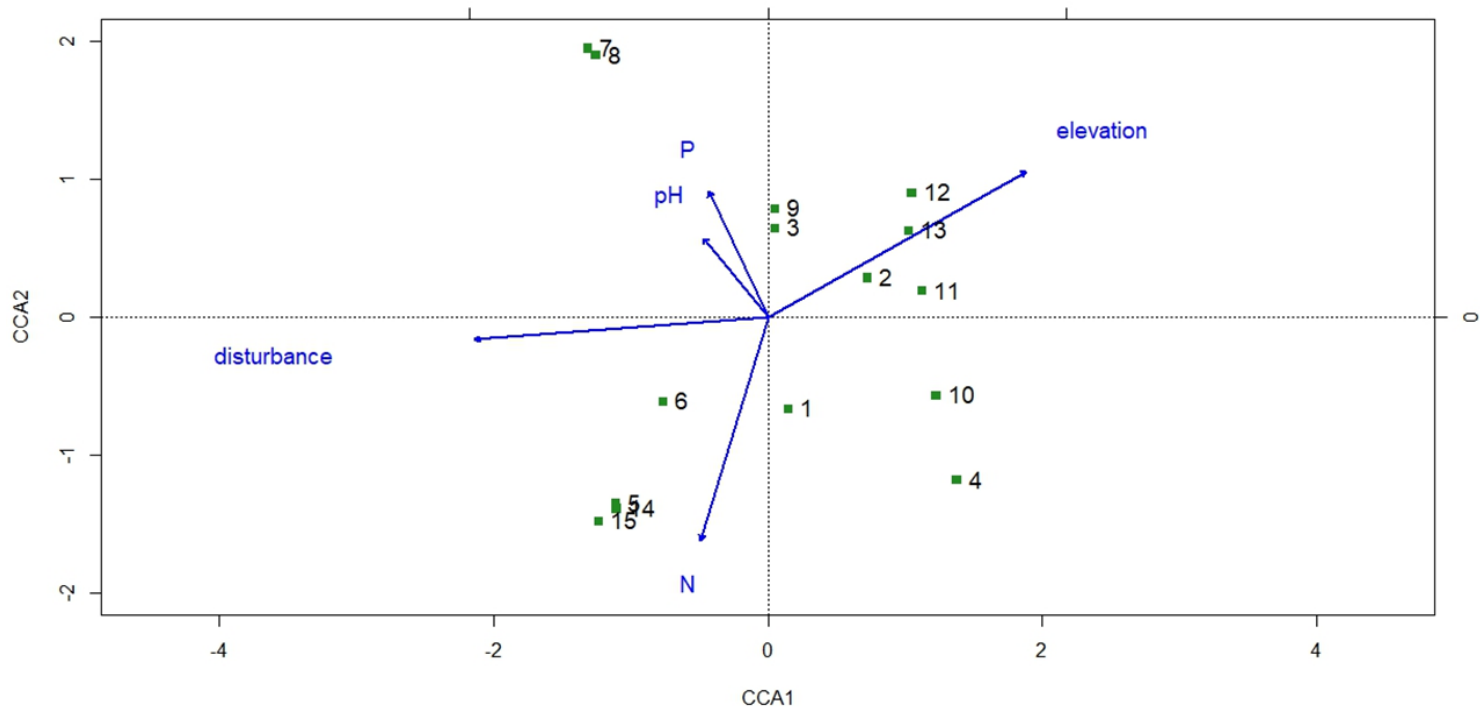

Figure 6. Ordination diagram showing the distribution of plots as influenced by environmental factors using Canonical Correspondence Analysis 
Table 1. Species composition along altitudinal gradients of Chaya mountain ranges, Mayoyao, Ifugao, Philippines showing Relative Basal Area (RBA). Dominant species are indicated with asterisk (*). Arrangement of taxa is according to elevation (from lowest to highest)

\begin{tabular}{|c|c|c|c|c|c|c|c|c|c|c|c|c|c|c|c|}
\hline Site number & 1 & 2 & 3 & 4 & 5 & 6 & 7 & 8 & 9 & 10 & 11 & 12 & 13 & 14 & 15 \\
\hline Plot name & 14 & 5 & 15 & 6 & 7 & 1 & 8 & 2 & 9 & 3 & 10 & 4 & 11 & 12 & 13 \\
\hline Elevation & 1047 & 1100 & 1101 & 1197 & 1300 & 1380 & 1406 & 1480 & 1510 & 1580 & 1608 & 1642 & 1714 & 1817 & 1916 \\
\hline Number of species & 45 & 34 & 17 & 33 & 12 & 19 & 23 & 21 & 29 & 55 & 32 & 51 & 29 & 51 & 38 \\
\hline Shannon_H (per plot) & 2.06 & 2.22 & 1.95 & 2.58 & 0 & 1.72 & 1.06 & 2.65 & 2.29 & 2.73 & 2.56 & 2.50 & 2.43 & 2.60 & 2.11 \\
\hline Maximum DBH (in cm) & 49 & 22 & 41 & 14 & 30 & 40 & 54 & 54 & 29 & 50 & 25 & 34 & 28 & 60 & 42 \\
\hline Minimum DBH (in cm) & 0.63 & 0.63 & 1.27 & 0.4 & 10.82 & 1.27 & 1.27 & 0.95 & 1.27 & 0.63 & 0.95 & 0.63 & 6.37 & 0.95 & 0.95 \\
\hline Maximum height (in m) & 26 & 15 & 22 & 18 & 10 & 16 & 14 & 20 & 15 & 20 & 16 & 18 & 8 & 16 & 16 \\
\hline Minimum height (in m) & 1.1 & 1.1 & 2.2 & 1.4 & 7 & 1.7 & 1 & 1.6 & 1.51 & 1.1 & 1.4 & 1.2 & 1.24 & 1.5 & 1.64 \\
\hline
\end{tabular}

\section{Name of species}

Gmelina arborea Roxb. ex Sm

Bischofia javanica Blume

Palaquium luzoniense (Fern.-Vill.) Vidal

Astronia candolleana Cogn.

Toona calantas Merr. \& Rolfe

Neonauclea reticulata (Havil.) Merr.

Pinus kesiya Royle ex Gordon

Swietenia macrophylla G. King

Pterocarpus indicus Herb. Madr. ex Wal

Garcinia venulosa Choisy

Radermachera acuminata Merr.

Weinmannia luzoniensis S. Vidal

Pfoloblo

Lithocarpus submonticola (Elmer) Rehder Litsea perrottetii (Blume) Fern.-Vill.

Unknown 1

Knema sp.

Semecarpus cuneiformis Blanco

Apfala

Clerodendrum sp.

Elaeocarpus sp.

Cleistocalyx opercitat

Gomphandra sp.

Clethra tomentella Rolfe ex Dunn

\section{Family}

Lamiaceae

Phyllanthace

Sapotaceae

Meliaceae

Pinaceae

Meliaceae

Fabaceae

Clusiaceae

Bignoniaceae

Cunoniaceae

Fagaceae

Lauraceae

Myristicaeae

Anacardiaceae

Lamiaceae

Elaeocarpaceae taudchachay

Mlaeocarpace

Icanicaceae

Clethraceae

\section{Local name}

melina

chalaan

pfangtinon

antap

benguet pine

mahogany

narra

pfaghapfajon

tabangawon

palajun

baan

mananor

lopot

\section{RBA RBA RBA RBA RBA RBA RBA RBA RBA RBA RBA RBA RBA RBA RBA}

\section{$93.09 * 87.19 * \quad 59.50 *$}

$0.664 .90^{*}$

$2.36 *$

$\begin{array}{ccccccccc}13.39^{*} & 0.86 & 0.20 & 2.45 & 0.96 & 0.76 & 3.22 & 0.86 & 9.74^{*} \\ 7.06^{*} & & & 53.59^{*} & & & & & \end{array}$

$\begin{array}{llll}3.85 & 1.52 & 100 * \quad 94.60 *\end{array}$

$43.98 *$

$6.12^{*}$

$11.86^{*}$

$10.26^{*}$

$0.05 \quad 0.23$

$4.76^{*} 33.45^{*}$

$0.45^{*}$

0.11

$76.05 * 20.79 *$

0.24

0.06

$51.36 * 80.92 * 50.92 *$

$12.46^{*}$
$9.65 *$

$1.01 *$

$14.40^{*}$

$4.99 *$

$10.10^{*}$

$0.0133 .46^{*}$

$\begin{array}{llrrr}0.10 & 0.84 & 6.59 & 2.97 * 28.95 *\end{array}$

$\begin{array}{llll}5.33 & 3.52 & 1.58 \quad 27.24 *\end{array}$

$12.17 *$

$0.09-16.9$

9.23

$\begin{array}{llll}.32 & 4.80 * & 6.64 & 0.23\end{array}$

$1.60 * \quad 2.49$ 


\begin{tabular}{|c|c|c|c|c|c|c|c|c|c|c|c|c|c|c|c|c|}
\hline Leucosyke capitellata (Poir.) Wedd. & Urticaceae & pfahog & & & & & & $27.46^{*}$ & & & & & & & & \\
\hline $\begin{array}{l}\text { Pfa'an } \\
\text { Pas }\end{array}$ & - & & & & 0.12 & & & $17.16^{*}$ & & & & & & & & \\
\hline Unknown 3 & - & & & & & & & & & & $48.70 *$ & & & & & \\
\hline Talana' small leaves & - & & & & & & & & $16.47^{*}$ & & & & & & & \\
\hline Ameleng & - & & & & & & & & $10.26^{*}$ & & & & & & & \\
\hline Cryptocarya paucinervia Gamble & Lauraceae & tempo & & & & & & & 0.01 & $17.95^{*}$ & 0.30 & & & 0.18 & 0.44 & 0.90 \\
\hline Palubphan & - & & & & & & & 7.59 & & $8.58 *$ & & $12.87 *$ & & & & \\
\hline Symplocos sp. & Symplocaceae & olatton & & & & & & & 0.32 & $7.60 *$ & 0.18 & 0.36 & & 0.09 & 0.16 & 0.16 \\
\hline Syzygium polycephaloides (C.B.Rob.) Merr. & Myrtaceae & ato ang-ang & & & & 2.30 & & & & & & & & & & \\
\hline Prunus pubescens Pursh & Rosaceae & alacheng & 0.01 & & & & & & 1.08 & & $20.98^{*}$ & & & 0.94 & 0.02 & \\
\hline Calophyllum soulattri "Burm." ex F.Mull. & Clusiaceae & bitaor & & & & & & & 2.28 & & $16.79 *$ & & & & 0.38 & \\
\hline Engelhardtia sp. & Juglandaceae & attapfong & & & & & & & & & & $13.74 *$ & & 1.20 & & 5.06 \\
\hline Cryptocarya lanceolata Merr. & Lauraceae & tuyphu & & & & & & & 4.81 & 3.67 & 1.22 & & & & 0.75 & 0.79 \\
\hline Chloranthus elatior $\mathrm{R} . \mathrm{Br}$. & Chloranthaceae & loblopfong & & & & & & & 0.03 & & & 0.06 & 0.42 & 0.45 & 0.05 & \\
\hline Eurya japonica Thunb. & Theaceae & penalenghengon & & 0.08 & 2.69 & & & 0.17 & 0.08 & 2.01 & & 0.80 & & & & 0.06 \\
\hline Evodia benguetensis Elmer & Rutaceae & & & & & & & & & & & & & & 1.30 & \\
\hline Mangifera indica $\mathrm{L}$. & Anacardiaceae & mangka & 1.29 & & & & & & & & & & & & & \\
\hline Coffea $\mathrm{sp}$ & Rubiaceae & coffee & 0.28 & & & 0.09 & & & & & & & & & & \\
\hline Glochidion sp. & Euphorbiaceae & amamokug & 0.16 & & & & & & & & & & & & & \\
\hline Ficus nota Merr. & Moraceae & lapfoy & 0.01 & 0.11 & & & & & & & & & & 0.18 & & \\
\hline Pfolo & - & & 0.01 & 0.11 & 1.34 & 0.02 & & & & & & & & & & \\
\hline Villebrunea trinervis Wedd. & Urticaceae & loppeng & & 0.81 & 3.90 & & & & & & & & & & & \\
\hline Fraxinus griffithii C.B.Clarke & Oleaceae & onop & & 0.28 & & & & & & & & & & & & \\
\hline Ficus annulata Blume & Moraceae & peggwe & & 0.07 & & & & 0.05 & & & & & & & & \\
\hline Callicarpa subintegra Merr. & Lamiaceae & atorpfo & & 0.04 & & & 0.03 & & & & & & & & & \\
\hline Deutzia pulchra S.Vidal & Hydrangeaceae & hana'te & & 0.02 & & & & 0.08 & & & & & & & & \\
\hline Melastoma malabathricum $\mathrm{L}$. & Melastomataceae & pfugtayun & & 0.02 & 0.69 & & 0.17 & 1.10 & & 0.36 & & & & & 0.02 & \\
\hline Grewia laevigata Vahl & Tiliaceae & alanchong & & & 3.27 & & & & & & & & & & & \\
\hline Alinaw & - & & & & 0.48 & & & & & & & & & & & \\
\hline Saurauia bontocensis Merr. & Actinidiaceae & choggoy & & & 0.21 & & & & & & & & & & & \\
\hline Saurania elegans Fern.-Vill. & Actinidiaceae & pfinor & & & 0.21 & & & & & & & & & & & \\
\hline Lanipaw & - & & & & 0.02 & & & & & & & & & & & \\
\hline Artocarpus heterophyllus Lam. & Moraceae & & & & & 7.59 & & & & & & & & & & \\
\hline Ficus odorata Merr. & Moraceae & apla & & & & 0.03 & & & & & & & & & & \\
\hline Macaranga dipterocarpifolia Merr. & Euphorbiaceae & anablon & & & & & & 0.07 & & & & & & & & \\
\hline Lachao & & & & & & & & 3.50 & & 5.56 & & 1.07 & & & & \\
\hline Leea aculeata Blume & Leeaceae & ang-ang & & & & & & 0.03 & & & & & 0.07 & & & \\
\hline Canthium ellipticum Hochst. ex Delile & Rubiaceae & & & & & & & & 1.07 & & & & & & & \\
\hline Helicia paucinervia Merr. & Proteaceae & lakot & & & & & & & 0.68 & & & 0.23 & & & & \\
\hline Antherostele callophylla Bremek. & Rubiaceae & lanuhi (kahoy) & & & & & & & 0.24 & & & & & & & \\
\hline Eurya japonica Thunb. var. nitida (Korth.) Dyer & Theaceae & & & & & & & & 0.21 & & & & & & & \\
\hline Praravinia viridescens (Elmer) Bremek. & Rubiaceae & lungtian & & & & & & & 0.10 & & & & & & & \\
\hline Unknown 2 & - & & & & & & & & 0.08 & & & & & & & \\
\hline Unknown 4 & - & & & & & & & & & 6.34 & & & & & & \\
\hline Archidendron clypearia ( Jack) I.C.Nielsen & Fabaceae & haguchachit & & & & & & & & 1.99 & 0.06 & & & & & \\
\hline
\end{tabular}




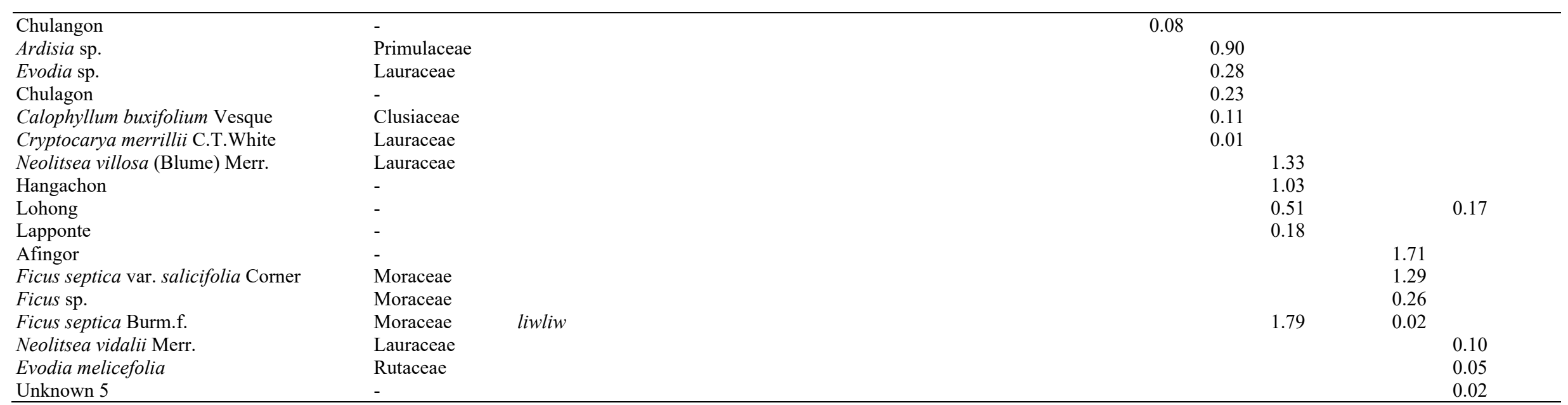


The presence of Pinus kesiya Royle ex Gordon, Gmelina arborea Roxb. and Swietenia macrophylla King could have a profound influence in the future of landscape's ecosystem services. Pine trees were reported to have allelopathic effect in plants and this can inhibit the growth of other trees (Kimura et al. 2015). In the same way, Swietenia macrophylla King is also allelopathic in nature (Mukaromah et al. 2017). Gmelina arborea Roxb. and Swietenia macrophylla King is a potential be bioinvasive species in the area as emphasized by Baguinon and Miel (2013).

In the study of Soriano et al. (2017), farmers in Kiangan, Ifugao perceived that the introduction of nonnative species in their forest led to the degradation of forest quality which in turn reduced the effective provision of ecosystem services of the forest. However, pinuchu is a privately managed forest and people use the abovementioned species for construction materials, so bioinvasion is less likely to occur. The high diversity index of the entire pinuchu in Chaya $\left(\mathrm{H}^{\prime}=3.83\right)$ is an evidence that bio-invasion is not yet happening. However, this should not be the reason to plant more introduced species in the locality, especially as reforestation planting material.

\section{Environmental variables influencing floristic diversity}

Environmental variables including elevation, temperature, soil characteristics, and anthropogenic disturbances were tested if they influence the floristic structure and zonation of the Chaya pinuchu. It was found out that elevation, temperature, and disturbance were positively influencing the structure of the pinuchu but soil nutrients and $\mathrm{pH}$ had minimal impact (Figure 6). This observation is similar to that of Sopsop and Buot (2013) where human disturbance (e.g. kaingin farming) impacted species composition. It is observable that as the elevation gets higher, native species belonging to the families of Fagaceae such as Lithocarpus submonticola (Elmer) Rehder dominated the area. This is because of the higher and steep slopes which make it difficult for humans to access the pinuchu, hence only lower elevation species were altered and planted with some introduced species. This was also observed by Buot and Osumi (2011) in their study in Mount Makiling.

Meanwhile, with higher elevation and hence, lower temperature, the species composition was dominated by Fagaceae and Lauraceae families. Fagaceae and Lauraceae were the dominant vegetation type in the mountains of tropical Asia (Sri-Ngernyuang et al. 2003) particularly, in higher elevation of Cordillera Mountain ranges (Buot 2014; Buot 2007; Buot and Okitsu 1998). Nitrogen also played a vital role in the distribution of species in plots 14 and 15 which were all in the lower elevation. This could be explained by possible accumulation of Nitrogen that has been leached from the upper slopes.

\section{The Chaya Pinuchu Biodiversity and its implication to resilience}

The species diversity ( $\left.\mathrm{H}^{\prime}\right)$ for the entire Chaya's pinuchu was 3.83 dit. Based on Fernando (1998) scale of diversity values, this is considered very high. Interestingly, Chaya's pinuchu is more diverse as compared to the diversity of Namnama, Alfonso Lista $\left(\mathrm{H}^{\prime}=3.59\right)$, Nagacadan, Kiangan $\left(\mathrm{H}^{\prime}=3.7\right)$ and Bato, Mayoyao, Ifugao $\left(H^{\prime}=3.6\right)$ as observed in the study of Taguiling (2014). This may be attributed to the fact that pinuchu in Chaya was located at a much higher elevation and hence, not highly disturbed as compared with the pinuchu in Alfonso Lista and Bato, Mayoyao which were being used for slash and burn farming (Taguiling 2014). Associated with its rich biodiversity is the availability of water resources which provided irrigation for the rice terraces.

The high diversity in Chaya's pinuchu is critical to resilience. In the face of environmental fluctuations, "biodiversity insures ecosystem health as many species provide greater support and some maintains functioning even if others fail" (Yachi and Loreau 1999). This insurance effect can help maintain a desirable ecosystem state for the CSEPL to continue provide ecosystem services for the entire socio-ecological system.

In conclusion, this study measured the ecological indicators of socio-ecological resilience by vegetation assessment and household survey. This was the first attempt to document the vegetation status of the biodiversity in the forest of Chaya. The study revealed that pinuchu of Chaya has now been planted with introduced species found in the lower slopes. Two of these species were the exotic fast-growing, Gmelina arborea Roxb and Swietenia macrophylla King. Elevation, $\mathrm{pH}$, temperature and human disturbances were influencing the vegetation structure. The species diversity was high $\left(\mathrm{H}^{\prime}=3.83\right)$. The pinuchu must be biodiversity-rich if the entire Chaya Socio-Ecological Production Landscape has to be resilient through the years. The presence of exotic species in the pinuchu of CSEPL requires certain steps to protect and conserve native biodiversity should these exotics naturally spread and harm the natural biota. Protection of biodiversity is indeed important to sustain its ecological function in the whole landscape. Policy makers and implementers need to patronize the use of pioneer native tree species as planting material in the reforestation program instead of using exotic fast-growing species.

\section{ACKNOWLEDGEMENTS}

The corresponding author would like to acknowledge the Ifugao Satoyama Meister Training Program (ISMTP) funded by Japan International Cooperation Agency (JICA) for adopting this research in their program, the Department of Science and Technology Science (DOST) through the Science Educational Institute (SEI) under the accelerated Science and Technology Human Resource Development (ASTHRDP) and the Southeast Asian Regional Center for Graduate Study and Research in Agriculture (SEARCA) for funding this research, the University of the Philippines Los Baños for the references and facilities provided. The authors would like to express their deepest gratitude to the local government of Mayoyao, Ifugao and the local people 
of Barangay Chaya for their active participation in this study.

\section{REFERENCES}

Backer CA, Bakhuizen van den Brink RC. 1965. Flora of Java (Spermatophytes Only) (Vol 1-3). The Ruksherbarium Leyden, Groningen.

Baguinon NT, Miel J. 2013. Threat of Potential Bioinvasion in a Natural Forest in Poitan, Banaue, Ifugao, Cordillera Administrative Region. Philippine J Science 142 (2): 101-113.

Banaticla MCN, Buot IE. 2005. Altitudinal zonation of pteridophytes on Mt. Banahaw de lucban, Luzon Island, Philippines. Plant Ecology 180 (2): $135-151$

Bergamini N, Dunbar W, Eyzaguirre P, Ichikawa K, Matsumoto I, Mijatovic D. 2013. Toolkit for the Indicators of Resilience in SocioEcological Production Landscapes and Seascapes (SEPLS). Bioversity International, Rome, Italy.

Buot IE, Okitsu S. 1998. Vertical distribution and structure of the tree vegetation in the montane forest of Mt. Pulog, Cordillera mountain range, the highest mountain in Luzon Is., Philippines. Veg Sci 15 (1): 19-32.

Buot IE. 2014. Zonation of Biodiversity in the Forests of Lasang Landscapes in the Philippines. Biocultural Landscapes. Springer, Dordrecht.

Buot IE, Osumi K. 2011. Land use type pattern and woody species composition near human-disturbed landscapes on Mount Makiling, Luzon Island. Amer J Environ Sci 7 (4): 306-315.

Buot IE. 2007. Vegetation zonation of Mt. Akiki, Cordillera mountain range, Benguet Province, Philippines. Asia Life Sci 16 (1): 53-70.

Camacho LD, Gevaña DT, Carandang AP, Camacho SC. 2016. Indigenous knowledge and practices for the sustainable management of Ifugao forests in Cordillera, Philippines. Int J Biodiv Sci Ecosyst Serv Manag 12 (1-2): 5-13.

Castonguay A, Burkhard B, Müller F, Horgan F, Settele J. 2016. Resilience and adaptability of rice terrace social-ecological systems: a case study of a local community's perception in Banaue, Philippines. Ecol Soc 21 (2): 15. DOI: 10.5751/ES-08348-210215

Cintron G, Novelli YS. 1984. Methods for studying mangrove structure. Mangrove ecosystem: research methods. 91-113. UNESCO.

DENR 2008. Conservation and Adaptive Management of Globally Important Agricultural Heritage Systems (GIAHS). The Ifugao Rice Terraces Philippine Project Framework

Dulay MP. 2015. Indigenous Agroforestry Systems of Ifugao, Philippines. Resour Environ 5 (1): 45-51.

Fernando ES. 1998. Forest formations and flora of the Philippines: Handout in FBS 21. College of Forestry and Natural Resources, University of the Philippines at Los Baños, Laguna, Philippines.

Fernando ES, Sun BY, Suh MH, Kong H, Koh KS. 2004. Flowering Plants and Ferns of Mt. Makiling. ASEAN-Korea Environment Cooperation Unit (AKECU), Seoul.

Jacobi J, Schneider M, Bottazzi P, Pillco M, Calizaya P, Rist S. 2013. Agroecosystem resilience and farmers' perceptions of climate change impacts on cocoa farms in Alto Beni, Bolivia. Renew Agric Food Syst 30 (2): 170-183.

Kimura F, Sato M, Kato-Noguchi H. 2015. Allelopathy of pine litter: delivery of allelopathic substances into forest floor. J Plant Biol 58 (1): 61-67.
Magcale-Macandog DB, Bragais MA, Mojica LP, Tingson KN, Liquigan, MBC B. 2013. Floristic Composition and Stand Structure of" Muyong" Systems in Banaue, Ifugao, Philippines. IAMURE Intl J Ecol Conserv 8: 45-64.

Merrill ED. 1923. An Enumeration of Philippine Flowering Plants. Vol. 14. Manila: Bureau of Printing. Retrieved on May 11, 2015 from http://goo.gl/ aIWQDq

Mukaromah AS, Purwestri YA, Fujii Y. 2016. Determination of Allelopathic Potential in Mahogany (Swietenia macrophylla King) Leaf Litter Using Sandwich Method. Indonesian J Biotechnol 21 (2): 93-101.

Ohsawa M. 1984. Differentiation of vegetation zones and species strategies in the subalpine region of Mt. Fuji. Vegetation 57 (1): 1552 .

Peterson G, Allen, CR, Holling CS. 1998. Ecological resilience, biodiversity, and scale. Ecosystems 1 (1): 6-18.

Rabena, Mark Anthony. 2015. A Vegetation Inventory of a Traditional Secondary Forest (Muyong) in Kinakin, Banaue, Ifugao, Northern Luzon, Philippines. Philippine J Syst Biol 9: 10-32.

Rojo JP. 1999. Revised lexicon of Philippine trees. College Laguna: Forest Products Research and Development Institute, Dept. of Science and Technology 484p.-. ISBN, 1126325432.

Santiago JO, Buot IE. 2018. Conceptualizing the Socio-Ecological Resilience of the Chaya Rice Terraces, a Socio-Ecological Production Landscape in Mayoyao, Ifugao, Luzon Island, Philippines. J Mar Is1 Cult 7 (1): 107-126.

Sarmiento G. 1986. Ecological features of climate in high tropical mountains. High altitude tropical biogeography, Oxford University Press, Oxford.

Serrano RC, Cadaweng EA. 2005. The Ifugao Muyong: sustaining water, culture and life. Search of excellence: exemplary forest management in Asia and the Pacific. Regional Community Forestry Training Center for Asia and the Pacific, Food and Agriculture Organization of the United Nations, Rome, Italy.

Sneath PH, Sokal RR. 1973. Numerical Taxonomy. The Principles and Practice of Numerical Classification. W.H. Freeman and Co., San Francisco, USA.

Sopsop LB, Buot IE. 2013. The Forest Types in Aborlan Guba System, Palawan Island, Philippines. IAMURE Intl J Ecol Conserv 7: 88.

Soriano MA, Herath S. 2018. Quantifying the role of traditional rice terraces in regulating water resources: implications for management and conservation efforts. Agroecol Sustain Food Syst 42 (8): 885-910.

Soriano MA, Diwa J, Herath S. 2017. Local perceptions of climate change and adaptation needs in the Ifugao Rice Terraces (Northern Philippines). J Mountain Sci 14 (8): 1455-1472.

Sri-Ngernyuang, Kriangsak. Kanzaki M, Mizuno T, Noguchi H, Teejuntuk S, Sungpalee C, Bunyavejchewin S. 2003. Habitat differentiation of Lauraceae species in a tropical lower montane forest in northern Thailand. Ecol Res 18 (1): 1-14.

Taguiling NK. 2014. Macrofloral biodiversity conservation in Ifugao. European Sci J 9 (10): 469-482.

Ter Braak CJ. 1987. The analysis of vegetation-environment relationships by canonical correspondence analysis. Theory and Models in Vegetation Science. Springer, Dordrecht.

Walker BH. 1992. Biodiversity and ecological redundancy. Conserv Biol 6 (1): 18-23.

Yachi S, Loreau M. 1999. Biodiversity and ecosystem productivity in a fluctuating environment: the insurance hypothesis. Proc Natl Acad Sci USA 96 (4): 1463-1468. 